\title{
女子に扣ける嗜好品及び食品嗜好と不定愁訴との関連
} 一嗜好の因子構造による解析一

$\begin{array}{lll}\text { 中村 裕之* } & \text { 田畑 } & \text { 正司* } \\ \text { 中村 栗山 典子* } & \text { 野原 } & \text { 聖一* }\end{array}$

\section{The Relationship of Favorite acceptances and Food Preferences to Equivocal Complaints in Women -Analysis by Factor Structure of Favorite Acceptances and Food Preferences-}

\section{Hiroyuki NAKAMURA*, Masaji TABATA*, Noriko KURIYAMA*, Hideki NAKAMURA* and Seiichi NOHARA*}

In order to clarify the involvements of acceptance of favorites such as tabacco, alcohol, coffee and tea in women's complaining, the relationship between their complaint and factor structure of preference, which was calculated by using factor analysis from acceptances of favorites and preferences for food groups classified 13 according to food composition table, was examined in 236 women aged $20-39$. The explanation of its relationship was performed by canonical discriminant analysis with 7 explanatory variables; its 4 factor scores, age, systolic, diastolic blood pressure and weight index examined simultaneously.

The results were as follows:

1) The 1st, 2nd, 3rd, 4th factor of preference by factor analysis was deduced to be that for volumed foods, side foods, modern foods and favorites, respectively.

2) The women with either of headache, constipation or coldness of extrimities, which were found to be specified complaints to women in another examination of comparing men's complaint was discriminated from women free from complaints by the 1st canonical discriminant variate, and the women with the other complaints was by the 2nd canonical discriminant variate. The size of explanatory variables for 1st canonical variate was the order of the 2nd, 1st and 4th factor of preference, and 2nd discriminant variate was large above all for age variable.

These results suggest that women's complaining of headahe, constipation and coldness of extrimities has deep relationship to no preference for side foods as well as preferences for favorites, while the other complaints being related especially to aging.

* 金沢大学医学部公衆衛生学教室

* Department of Public Health, School of Medicine, Kanazawa University 


\section{I 緒 言}

近年，女子がタバコ，アルコール，コーヒー， 紅茶などの嗜好品と接する機会が増加してきた。 これらの嗜好品が原因と考光られる疾病もあるけ れども，直接的な因果関係であるかどうかについ ては議論の多いものもある。その理由としては, 嗜好品をたしなむことに関連する性格的要因や, 嗜好品をたしなむことにより他の一般食品への嗜 好や摂取頻度が变化するといら要因も無視できな いことが挙げられる(中澤ら，1986，小川，1980). 一方, 食物摄取に怙いては, ある種の食品群間に 正の相関関係が大きいといら補完的関係が存在す ることが認められている(豊川ら，1977，1981a). したがって, これらの嗜好品及び食品嗜好と不定 愁訴の関係を個々に調べるよりはむしろ，それら を嗜好の構造として包括し，この構造と不定愁訴 との関連を論じることが妥当であると思われる。 本研究では, 嗜好品及び食品嗜好に潜む構造を因 子分析により決定し, この因子構造と女子の不定 愁訴との関連を調べることにより, 嗜好品や一般 食品の嗜好度が女子の不定愁訴に与学る影響を検 討した.

\section{II 方 法}

\section{1. 対象及び調査項目}

金沢市, 富山市の会社 5 社を訪問し, アンケー 卜調査によって回答の得られた男女のらち, 20３9歳の女子 236 人を対象とした. 内訳は, 事務 従事者152例 (64\%), 技術的職業従事者34例 (14\%)，生産工程従事者50例（21\%）ですべて, 都市部あるいは都市近郊に住む有職婦人である。 吉田ら（1987）の栄養調查によって, よく食べら れていると思われた102種の食品の喍好, コー ヒー・紅茶の嗜好, 飲酒・喫煙習慣をアンケート 調查によって調查した。同時に, 収縮期血圧, 払 張期血圧, 身長, 体重と調查した。な抏, 調查は 昭和 62 年 4 月〜 5 月に実施した。

2. 一般食品及び嗜好品の嗜好分析

102の食品及び, コーヒー・紅茶に対して, “嫌
い”,“どちらかといえば嫌い”，“普通”，“どちら かといえば好き”，“好き”の 5 つの評価のうち 1 つを選択させ， 1 ～点の点数を各食品に与光， 食品群毎に平均点を求め, これを各食品群への個 人の嗜好度とした。 上記食品群の分類にあたって は，日本食品標準成分表（神立ら，1985）で用い られている食品分類を参考に102の食品を13種の 食品群 (魚介類 22 品, 肉類 4 品, 卵類 2 品, 豆・ 豆製品類 11 品, 乳・乳製品類 3 品, 小魚類 3 品, 海草類 5 品, 緑黄色野菜類10品, 淡色野菜類 16 品, 果物類 12 品, 穀類 5 品, いも類 3 品, 菓子類 6 品) に分類した，飲酒頻度及び契煙習慣の得点につい ては，それぞれ，1週間当りの飲酒日数と，1日 当りの䒜煙本数をそのまま用いた。これらの各食 品群及びューヒー・紅茶と飲酒, 契煙の各得点か ら, Pearson の積率相関係数を算出した。この相 関係数行列を基に，因子分析（主因子法）を用い， 第 4 因子まで求め, ここで単純構造を得るため Varimax 回転を適用し, その結果, 一般食品と コーヒー・紅茶の嗜好度及び领酒, 契煙状況につ いての回転後因子負荷量行列を得た。な拉, 対象 に怙いて㓶煙者は47人（19.9\%）で契煙率は全国 平均をやや上回るものであった（日本たばこ産業 株式会社, 1987). また, 乫煙者の 1 日平均妿煙本 数は7.5本であった。

3. 愁訴分析

対象とした $236 人 に$ 対し，1. 頭痛，2，めまい 耳鳴り，3. 咳・疢，4.肩こり・首のはり，5. 胃 痛, 6. 便秘, 7. 腰痛, 8. 手足の冷兄, 9. 疲れ やすい, 10。風邪をひきやすい, 11. 睡眠障害の 11の愁訴の有無を尋ねた。ささらに, 女子特有の愁 訴を特定化するため, 対象とした 236 人の中で, 男 子と年龄, 会社, 作業状況の点で正確にマッチす る女子 110 人を選び, 対応する男子 110 人に対し, この11の愁訴の発現頻度について $x^{2}$ 検定により 解析した。

4. 喍好の因子構造と女子の不定悠訴の関連に 対する分析

$\chi^{2}$ 検定により，女子には有意に高頻度を出現す る, あるいはその傾向ありと認められた頭痛, 便 


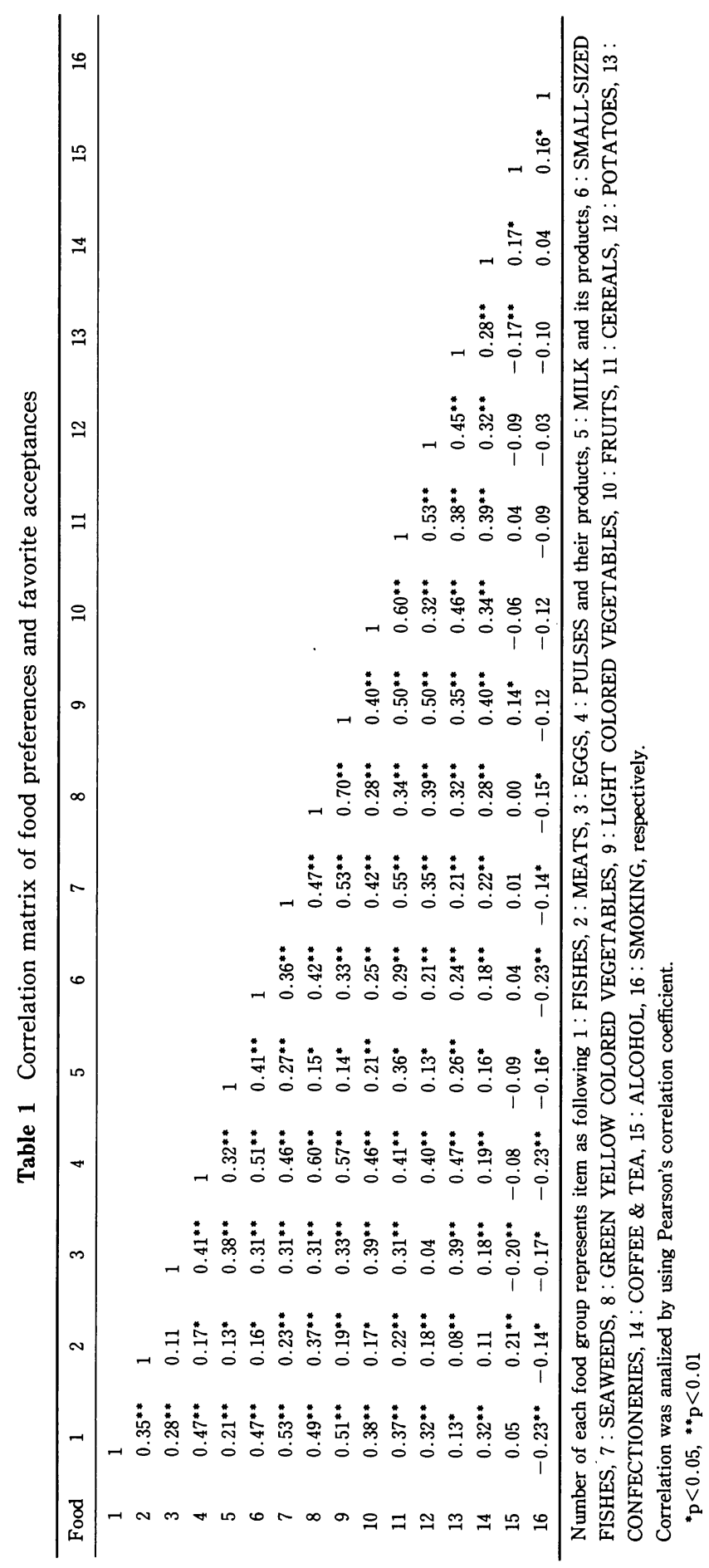


秘，手足の冷光を女子特有の不定愁訴として考兄 (結果の項で再述)，このらちのいずれかを有する 人を $\mathrm{A}$ 群, これらの愁訴を有さないが他のいずれ かの愁訴を有する人を $\mathrm{B}$ 群, 全く愁訴を有さない 人を $\mathrm{N}$ 群に分類した。この 3 群の判別にあたっ て，前記の因子分析によって得られた各個人の因 子得点(第 1 , 第 2 , 第 3 , 第 4 ), 年齢, 収縮期 血圧, 払張期血圧，肥満度の 7 変数を説明変数之 し, 正準判別分析を行い, 各説明変数に対し第 1 , 第 2 標準化正準変量を得た。な拉, 個人の肥満度 については，体重 $(\mathrm{kg}) \times 100 /($ 身長 $(\mathrm{cm})-100) /$ 0.9 により求めた。

\section{III 成}

\section{績}

\section{1. 一般食品及び㬐好品の嗜好分析}

食品群及び领酒，乫煙摄取量間の相関係数を Table 1 亿示す。13の食品群間には肉類一卵類, 卵類一いも類の 2 通りの組合せを除いてすべて有 意な正の相関が認められた。コーヒー・紅茶と一 般食品群との相関に招いても肉類を除く 12 食品群 に対し，正の相関が認められた。飲酒頻度の一般 食品群への相関については, 肉類, 淡色野菜類に 対し，正の相関が，卵類，菓子類に対し負の相関 があり, 哭煙本数の一般食品群への相関について は, 魚介類, 肉類, 卵類, 豆・豆製品類, 乳・乳 製品類, 小魚類, 海草類, 緑黄色野菜類の 8 食品 群に対し，負の相関があった、コーヒー・紅茶の 嗜好度, 飲酒頻度, 哭煙本数の赀好品間の関係に ついては，コーヒー・紅茶と飲酒頻度，领酒頻度 と䒜煙本数の間に正の相関が認められたが，コー ヒー・紅茶と契煙本数の間には有意な関係は認め られなかった。

因子分析による解析の結果 (Table 2) では，各 1 4 因子の固有值が 1 以上であり個々の因子が 有する共通性を推測するに十分な大きさであっ た.第 1 因子に負の值で 0.7 以上の大きい負荷量を とるものとして, 果物類, 款類, いも類, 菓子類, コーヒー・紅茶が，第 2 因子に正の值で 0.7 以上の 大きい負荷量をとるものとして，魚介類，肉類， 豆・豆製品類, 小魚類, 海草類, 緑黄色野菜類,
Table 2 Factor loading matrix of food preferences and favorite acceptances after orthogonal rotation

\begin{tabular}{|c|c|c|c|c|}
\hline \multirow{2}{*}{ Food group } & \multicolumn{4}{|c|}{$\begin{array}{l}\text { Factor loadings after } \\
\text { orthogonal rotation }\end{array}$} \\
\hline & $\begin{array}{l}\text { 1st } \\
\text { factor }\end{array}$ & $\begin{array}{l}\text { 2nd } \\
\text { factor }\end{array}$ & $\begin{array}{l}\text { 3rd } \\
\text { factor }\end{array}$ & $\begin{array}{l}\text { 4th } \\
\text { factor }\end{array}$ \\
\hline Fishes & -0.27 & 0.92 & -0.24 & 0.14 \\
\hline Meats & 0.02 & 0.86 & -0.13 & 0.49 \\
\hline Eggs & -0.34 & 0.25 & -0.85 & -0.31 \\
\hline Pulses & -0.53 & 0.71 & -0.33 & -0.33 \\
\hline Milk & -0.14 & 0.12 & -0.98 & 0.03 \\
\hline Small fishes & -0.10 & 0.74 & -0.66 & -0.02 \\
\hline Seaweeds & -0.54 & 0.78 & -0.32 & 0.09 \\
\hline Green veg. & -0.44 & 0.89 & 0.03 & -0.10 \\
\hline Light veg. & -0.69 & 0.72 & 0.04 & 0.06 \\
\hline Fruits & -0.85 & 0.22 & -0.48 & -0.02 \\
\hline Cereals & -0.85 & 0.29 & -0.40 & 0.19 \\
\hline Potatoes & -0.90 & 0.35 & 0.22 & -0.12 \\
\hline Confectioneries & -0.85 & 0.04 & -0.32 & -0.40 \\
\hline Coffee \& tea & -0.80 & 0.11 & -0.21 & 0.55 \\
\hline Alcohol & 0.09 & 0.17 & 0.11 & 0.98 \\
\hline Smoking & -0.30 & -0.66 & 0.35 & 0.60 \\
\hline eigenvalue & 3.18 & 3.14 & 1.88 & 1.38 \\
\hline $\begin{array}{l}\text { contribution } \\
\text { rate }(\%)\end{array}$ & 19.9 & 19.6 & 11.8 & 8.6 \\
\hline
\end{tabular}

Factor loadings were calculated by principal factor analysis and rotation of factor axes was performed using varimax method.

Table 3 Correlation of each factor score to physical characteristics

\begin{tabular}{lrrrr}
\hline & Age & Sys. BP & Dia. BP & $\begin{array}{l}\text { Weight } \\
\text { index }\end{array}$ \\
\hline 1st factor score & 0.055 & 0.028 & 0.043 & $-0.143^{*}$ \\
2nd factor score & -0.015 & -0.023 & -0.053 & -0.073 \\
3rd factor score & $0.118^{+}$ & 0.021 & 0.071 & 0.019 \\
4th factor score & 0.050 & 0.038 & 0.057 & 0.018 \\
\hline
\end{tabular}

Each factor score is the value calculated by factor analysis of food preferences and favorite acceptances.

Correlation was analized by using Pearson's correlation coefficient;

${ }^{+} \mathrm{p}<0.10{ }^{*} \mathrm{p}<0.05$

淡色野菜類が, 第 3 因子負荷量では負の值で 0.7 以 上の大きい值をとるものとして，卵類，乳・乳製 品類が, 第 4 因子負荷量では 0.5 以上大きい值をと 
るものとして, コーヒー・紅茶, 飲酒頻度, 喫煙 本数があげられる。これらの 4 つの因子に対する 各個人の得点と年齢，収縮期血圧，拡張期血圧， 肥満度との相関を Table 3 亿示す. 第 1 因子得点 と肥満度の間には負の有意な相関を，また，第 3 因子得点と年齢との間には正の相関を有する傾向 を示した。

\section{2. 愁訴分析}

年齢，会社，作業の点でマッチされた男女各 110 人の 11 愁訴の出現頻度を比較した (Table 4). 女 子に有意に高頻度に出現した愁訴は，便秘及び手 足の冷えの 2 愁訴であり，頭痛は女子に多く出現 する傾向を有した，全女子対象者236人中，便秘， 手足の冷光，頭痛の 3 愁訴のいずれかを有する人 （A 群）は103人，これらの愁訴を有さないが他の 8 愁訴のいずれかを有する人（B 群）は67人, 全 く愁訴を有さない人（N 群）は66人であった。

3. 嗜好の因子構造と女子の不定愁訴の関連に 対する分析

$\mathrm{A}, \mathrm{B}, \mathrm{N}$ の 3 群に対する正準判別分析の結果を Table 5 に示す．第 $1 ， 2$ 正準変量の相関係数に 対し,バートレットの $\chi^{2}$ 值を用いたとき(柳井ら，
Table 4 Number of subjects with each complaint according to sex

\begin{tabular}{lcc}
\hline \multicolumn{1}{c}{ Complaints } & $\begin{array}{c}\text { Women } \\
\text { Number } \\
\text { (\% of total) }\end{array}$ & $\begin{array}{c}\text { Men } \\
\text { Number } \\
\text { of total) }\end{array}$ \\
\hline Headache & $17^{+}$ & 9 \\
Vertigo or Tinnitus & $5.5)$ & $(8.2)$ \\
Cough or Sputum & $(4.5)$ & $(6.4)$ \\
Discomfort of shoulder & 8 & $17^{+}$ \\
or neck & $(7.3)$ & $(15.5)$ \\
Discomfort of stomach & 46 & 40 \\
region & $(11.8)$ & $(36.4)$ \\
Constipation & $(13.6)$ & $(17.3)$ \\
& $\left(33^{* *}\right.$ & 15 \\
Lumbago & 19 & $(13.6)$ \\
Coldness of extrimities & $(17.3)$ & 25 \\
Easy fatigability & $15^{* *}$ & $(22.7)$ \\
Easy to catch common & $(13.6)$ & $(1.8)$ \\
cold & 37 & 26 \\
Sleep disturbance & $(33.6)$ & $(23.6)$ \\
& $(10.9)$ & 12 \\
no complaint & $(10.9)$ \\
\hline & $(9.1)$ & $(14.5)$ \\
\hline
\end{tabular}

Statistical analysis was performed using Chisquare test. Significantly or likely larger propotion compared to its corresponding value ; ${ }^{+} \mathrm{p}<0.10{ }^{*} \mathrm{p}<0.05{ }^{* *} \mathrm{p}<0.01$

Table 5 Canonical discriminant variates and averages of explanatory variables according to complaint groups

\begin{tabular}{|c|c|c|c|c|c|}
\hline \multirow{2}{*}{$\begin{array}{l}\text { explanatory } \\
\text { variables }\end{array}$} & \multicolumn{2}{|c|}{ Standard canonical variates } & \multicolumn{3}{|c|}{ Complaints group ${ }^{\mathrm{a}}$} \\
\hline & $\begin{array}{c}1 \text { st } \\
\text { variate }\end{array}$ & $\begin{array}{l}\text { 2nd } \\
\text { variate }\end{array}$ & $\stackrel{\mathrm{A}}{(\mathrm{n}=103)}$ & $\stackrel{B}{B}=67)$ & $\stackrel{N}{N}=66)$ \\
\hline 1st factor score ${ }^{\mathrm{b}}$ & 0.65 & -0.18 & -0.03 & 0.037 & 0.03 \\
\hline 2nd factor score & 0.98 & -0.37 & -0.46 & 0.32 & 0.38 \\
\hline 3rd factor score & 0.02 & -0.16 & 0.28 & -0.21 & -0.23 \\
\hline 4 th factor score & -0.48 & -0.03 & 0.42 & -0.30 & -0.24 \\
\hline Age & 0.10 & 0.99 & 27.5 & 30.3 & 25.1 \\
\hline Sys. B.P. & 0.19 & 0.03 & 111.7 & 111.5 & 112.3 \\
\hline Dia. B.P. & -0.03 & -0.63 & 65.8 & 64.1 & 67.8 \\
\hline Weight index & -0.37 & -0.19 & 102.4 & 99.2 & 99.9 \\
\hline correlation $^{c}$ & $0.47^{* * *}$ & $0.38^{* * *}$ & & & \\
\hline
\end{tabular}

a : Person of A group has more than one of complaints of headache, constipation and coldness of extrimities, person of $B$ group does'nt have any of those complaints but has other complaints and person of $\mathrm{C}$ group has no complaint.

$\mathrm{b}$ : Each factor score is the value calculated by factor analysis of food preferences and favorite acceptances.

c : Analysis of canonical correlation coefficients was performed using Barlett's Chisquare value $;{ }^{* * *} \mathrm{p}<0.001$ 


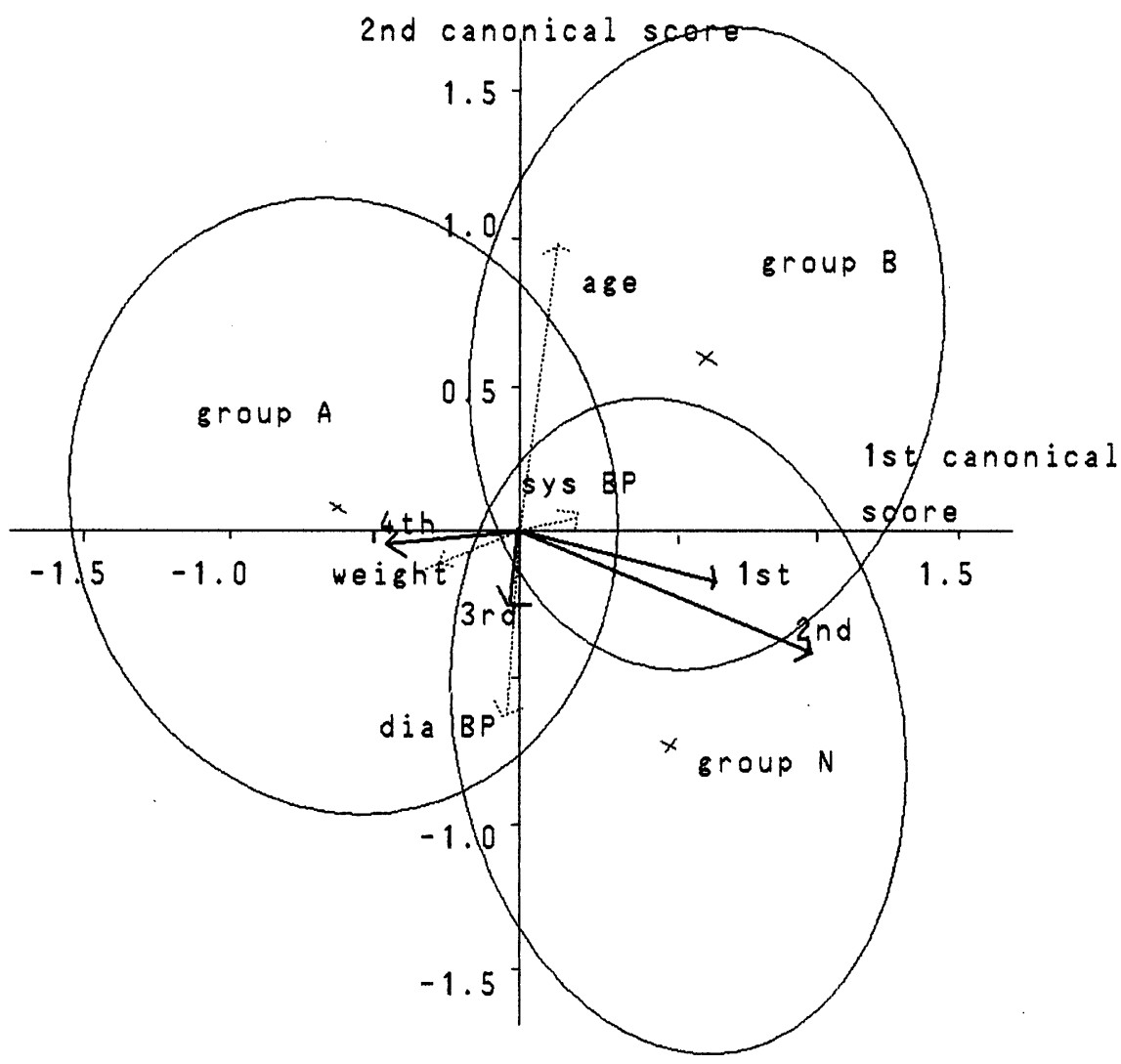

Fig. 1 The schema of canonical discriminant scores and variates See text for further details of this figure

1986）のそれぞれの限界確率は0.001以下であり， この正準変量が有意であることが示された。 また， この判別分析に打ける“見かけの的中率”は $65.7 \%$ と比較的大さい值であり，3 群がよく判別されて いることが示された。標準化された第 1 正準変量 では第 2 因子得点に対して0.98 と特に大きく, 次 に, 第 1 因子得点に対し 0.65 と大きい値を示した。 第 2 正準変量では年齢に対して0.99と特に大き く, 次いで拡張期血圧に対しー0.63と大きい値を 示した.これらの様子を視覚的に Fig. 1 で示す。 すなわち, 各説明変数に対する第 1,2 正準変量 のそれぞれの值をべクトルで示すと同時に，A， $\mathrm{B}, \mathrm{N}$ 各群の正準得点に対する $68 \%$ 集中楕円を描 き，その重心をプロットした. $\mathrm{N}$ 群の重心に対し， $\mathrm{A}$ 群のそれは横軸の負の方向に，B 群のそれは䅠
軸の正の方向に認められたことから，特に第 1 正 準変量が $\mathrm{A}$ 群に，第 2 正準変量が $\mathrm{B}$ 群に判別す るのに寄与していることが示された。

\section{IV 考察}

タバコ,アルコール, コーヒー, 紅茶などの㫮 好品をたしなむことにより, 疾病の発生のリスク が増大するが，暂好品をたしなむ根底に未知の因 子が存在することも原因となり得る（久道ら， 1982). 契煙による発癌性や循環器系の影響をみる 場合には, 食塩や香辛料などの栄養学的要素や コーヒー，アルコールなどの他の因子に言及する ことは当然必要となってくるように，喍好品と不 定愁訴之の関連性を捉えるにあたっても，一般食 品に対する嗜好の特性を無視することはできな 
い. 掣煙行動や食品嗜好が性格的因子と関連深い (小川, 1980, 垣本, 1977) ことも知られて扣り, 嗜好品や食品嗜好と不定愁訴との関連性を検討す る上では，嗜好品を含めた上での，諸食品に対す る嗜好に対する潜在的因子を見いだし，その因子 構造と不定愁訴との関連性を調べることが意義深 いと考えられる。

また，食品摄取について報告した豊川ら (1977， 1981a)によれば, 食品摄取構造には多食因子が存 在し, 食品群間の相関行列には補完的関係が多い といら。本研究に扣ける食品嗜好に扣いても, 食 品群間には極めて高い正の相関関係が, また, 嗜 好品間においても正の相関関係が認められた。 そ の一方では, 契煙本数について 8 つの食品群に対 して負の相関関係が認められた. したがって, こ の相関関係に潜む嘫好の構造を理解するために は, 因子分析による各因子の特徵的な嘫好構造を 推測することが重要となる.

因子分析により求められる第 1 因子では，果物 類, 俱類, いも類, 菓子類, コーヒー・紅茶が大 きい負荷量を呈した。款類, いも類が炭水化物性 の食品であるため，この第 1 因子の嗜好構造から 推測される嗜好型は炭水化物性食品嗜好型といえ る.しかし，この第 1 因子得点の絶対值は肥満度 と正の相関を有することや，款類が主食であるこ と, 菓子類の過度の摄取が肥満の原因となり得る ことを考えればこの第 1 因子は“量を嗜好する因 子” (factor of preference for volumed foods) と説明できる。第 2 因子負荷量では，魚介類，肉 類, 豆 - 豆製品類, 小魚類, 海草類, 緑黄色野菜 類, 淡色野菜類が大きい值を得た。米や麦の主食 に対し, 副食品に相当する食品群がこの因子を占 めるため，第 2 因子を“副食品嗜好因子”（factor of preference for side foods）と考えられること ができる、しかも，中島ら（中島ら，1983）が, 食品摄取の分析から副食品因子が多食性を規定す ると指摘しているよらに，この副食嗜好因子には 特定の食品に対する嘴好といらより, むしろ, 幅 広い食品嗜好すなわち食品嘴好に偏りがないとい らことが含まれていると考えられる，第 3 因子負
荷量では，卵類，乳・乳製品類が大きい值を呈し た. 乳・乳製品類がいわゆる近代的食品の代表で ある（豊川ら，1975）ことや，この因子得点の絶 対値が年齢と負の相関関係を有する傾向があるこ とから, 第 3 因子を“近代的食品嗜好因子” (factor of preference for modern foods）と読みとるこ とが可能である．第 4 因子では，コーヒー・紅茶， 飲酒頻度, 契煙本数の嗜好品に対して大きい負荷 量を得た。したがって，この因子は “嗜好品嗜好 因子”（factor of preference for favorites）と捉 えることがでさる。この第 4 因子負荷量に対し， 一般食品の中でとりわけ肉類が大きい值を示した ことは興味深い. 肉類に扣いても近代的食品の 1 つとして捉えることができ(豊川ら，1975），また， 肉類の食物消費を，経済的面から贅沢的パターン の 1 つして解釈した豊川らの報告 (1981b)を考 えれば，近代的女子が嗜好品に対する欲求が大き

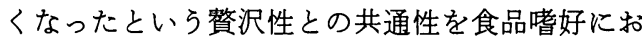
いて見いだすことができる。したがって，この第 4 因子を“贅沢性の因子”（factor of luxury）と して読みとることも可能である.

これら 4 つの因子に年齢，収縮期血圧，払張期 血圧, 肥満度の身体的特徵を加えて, 女子の愁訴 との関連を分析した正準判別分析の結果は図 1 に 模式化して描かれている. 各群と説明変数の関連 については, その説明変数がつくるベクトルのそ の群の重心方向, あるいは反対方向への成分が大 きいとき，その関連が大きいと見なせる、第 2 因 子得点はその因子の意味に対し正の値で, 第 1 因 子得点は負の値で示されるため, 女子特有の愁訴 である頭痛, 便秘, 手足の冷え（A 群）との関連 は第 2 因子である“副食品嗜好因子”が最も大き く，第 1 因子である“量を嘫好する因子”がこれ に次いで大きい，しかし，第 4 因子である“嗜好 品哓好因子”はこの 2 つ因子よりさらに小さい ことが読みとることができる. 個々の説明変数が まったく独立ではないため, 説明変数と群との関 連の解釈は慎重でなければならないが，巨視的に みれば，副食を嗜好しない女子や量を好む女子に はこの 3 愁訴を呈しやすいことが示唆される。ま 
た，嗜好品をたしなむ女子も愁訴の発現に関与し ていることが推測されるが，この嗜好品の関与の 程度は, その判別変量の大きさから食品嗜好上の 問題ほど大きいものではないことが䂏い知れる。 一方, “量を嘴好する因子”が肥満度と関連がみら れ，また，この因子は女子特有の愁訴之関連深い といら結果であった. さらに, 肥満度はその判別 変量は小さいが, これが大きいとき，これらの愁 訴を有する女子と判別されていた，結局，この因 子は, 背景に肥満を増長するような食品嗜好の偏 りを通して，女子特有の不定愁訴の発現に影響を 及ぼしていると推測できる。これに対して, 前述 したように“副食品嗜好因子”に嗜好の偏りがな いといらことが含まれて考学られることから，女 子特有の愁訴発現には特に喍好の偏りが大いに関 連しているといえる。

女子特有ではない愁訴 (B 群) は, 第 2 正準変 量にとりわけ大きい值を示す年龃の因子との関連 が強い．年龄と反対方向には第 3 因子である“近 代的食品喍好因子”之拡張期血圧が位置した。 前 者は年龄と逆相関がみられたことや, 後者が若年 女子に低い值を呈しやすいことは，ともにB 群と の関連に颃いては年齢的因子が重要であることを 覞わせる。すなわち, 頭痛, 便秘, 手足の冷兄の 3 愁訴が, 各個人の栄養学的嗜好上の特性ならび に嫩好品摄取と密接な関連をもって発現するもの と考学られるのに対し, めまい耳鳴り, 咳・痰, 肩こり・首のはり, 胃痛, 腰痛, 疲れやすい, 風 邪をひきやすい，睡眠障害の愁訴は女子が避ける ことができない加秢現象のための訴えであると考 えられる。

食習慣には地域性とのつながりや職業といった 社会属性の因子も加わるように, 食品赀好が集団 の特性によって異なことも十分考えられる，本研 究では地方都市あるいはその近郊に住む有職女子 を対象としたが，以上のような暂好品及び食品喍 好と女子の不定愁訴との関連が普遍的なものかど らかは,さらに対象を变えての調査に期待しなけ ればならない。

\author{
V ま と め \\ タバコ, アルコール, コーヒー, 紅茶の嗜好品
} が女子の不定愁訴の発現に如何に関連しているか を明らかにするため, 年歯2 20 - 39歳の 236 人の女子 に怙ける嗜好品摂取及び食品成分表から分類され る食品群の嗜好状況を基に因子分析により，嗜好 の因子構造を解析し，これと不定愁訴との関連が 調べられた。 その関連を調べるにあたり, 因子分 析から求められた 4 つの因子得点に, 同時に調查 した年龄, 収縮期血圧, 払張期血圧, 肥満度を加 えた 7 つ説明変数により正準判別分析が行われ た.

その結果は以下の如くである.

1）第 1 , 第 2 , 第 3 , 第 4 因子はそれぞれ, 量 を嗜好する因子, 副食品嗜好因子, 近代的食品嗜 好因子，嗜好品嗜好因子（政沢性の因子）と捉克 ることができた。

2）男子の愁訴との比較により,女子特有の愁訴 と特定できた頭痛, 便秘, 手足の冷えのいずれか を訴える女子は，第 1 正準変量によって，また， この 3 つの愁訴以外を呈する女子は第 2 正準変量 によって無愁訴者とよく判別できた。第 1 正準変 量に対しては第 2 因子が特に大きく，第 1 因子は これに次いで大きいが，第 4 因子である嗜好品嗜 好因子はこの 2 者より小さかった。第 2 正準変量 に対しては，とりわけ年齢の因子が大きかった。

これらの結果から，女子非特有の愁訴が加齢現 象として捉えられるのに対し，女子特有の愁訴で ある頭痛, 便秘, 手足の冷觉の発現には, 暂好品 をたしなむ因子はもちろん，それ以上に食品赀好 の偏りと密接な関連が示唆された.

本文の一部は第 52 回日本民族衛生学会総会（高山） にて発表した。

\section{文献}

浅野牧茂 (1980): タバコの生理学的影響, からだの 科学, $93,84-89$

久道 茂, 清水弘之, 深尾 彰訳 (1986)：臨床のた めの疫学, 246-269, 医学書院 (東京)

Fletcher, R.H., Fletcher, S.W. \& Wagner, E.H. 
(1982): Clinical Epidemiology-the essentials, Wiliams \& Wilkins (USA)

垣本 充 (1977)：食品箸好性の精神身体医学的研究 一短期大学生の野菜類嫩好について一, 栄養学雑誌, 35(3), 137-142

神立 誠，山本喜男，小笠原ゆり監修（1985）：食品 成分表, 一橋出版（東京）

中澤三郎，芳野純治，中村常哉（1986）：嗜好品之疾 患，日本薬剤師会雑誌，38(6)，537-544

中島順一, 吉川周子（1983）：食物消費構造に括ける 多食性因子の除外，民族衛生，49(2)，59-66

日本たばこ産業株式会社（1987）：昭和61年全国たば こ哭煙者率調査調査結果の概要，日本たばこ産業株 式会社

小川 浩 (1980)：乫煙習慣の社会的・心理的背景, 現代医学, 28(1), 119-126

豊川裕之, 三宅由子, 伊藤雅治 (1975)：わが国の食 物摄取に関する研究（第 1 報）全国規模の分析, 日
本公衛誌，22(10)，571-584

豊川裕之（1977）：食物消費構造の理論と応用，公衆 衛生, 41(5), 358一-365

豊川裕之，丸井英二，小野田博一，木村信子，吉田節 子，金子 俊，山上雅子，永山育子，赤羽正之，西 岡葉子, 石井荘子, 森口 覚(1981a)：東京近郊農 村婦人（30-69歳）の食物消費パターン，栄養と食 糧, 34(6)，531-543

豊川裕之, 市川雅教, 松村康弘, 丸井英二, 金子 俊, 三宅由子（1981b）：食物消費パターンの変遷と経 済成長，民族衛生，47(3)，138-147

柳井晴夫, 高木廣文 (1986)：多变量解析ハンドブッ ク, 254-262, 現代数学社 (京都)

吉田繁子, 若林敏子, 出宮一徳 (1987)：老人の食喈 好々食物摂取行動一 3 世代同居世帯の老人の場合 一, 栄養学雑誌, 45(1), 11-22

（受稿 1987．11．5） 